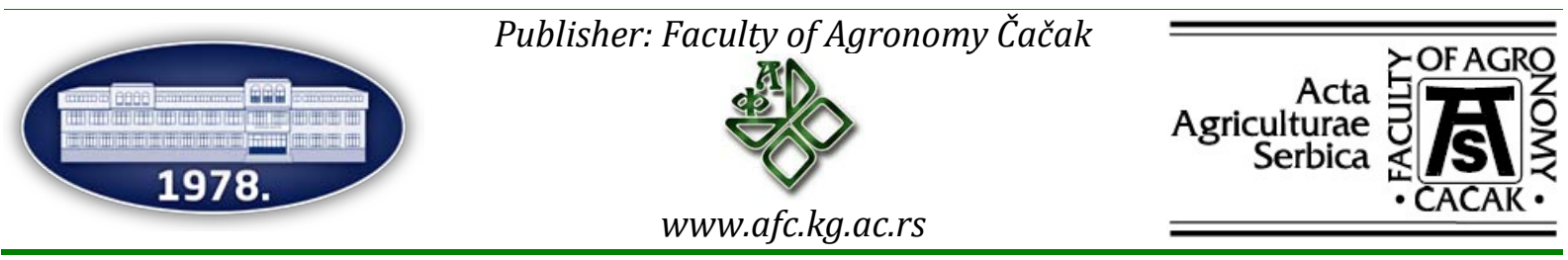

\title{
Influence of the fertilizers Slavol and Biohumus on potato leaf area and stomatal density
}

\author{
Elizabeta Miskoska-Milevska ${ }^{*}$, Daniela Dimovska² ${ }^{2}$ Zoran T. Popovski ${ }^{1}$, Igor Iljovski ${ }^{1}$ \\ ${ }^{1}$ Ss. Cyril and Methodius University, Faculty of Agricultural Sciences and Food, Blvd. Aleksandar Makedonski b.b. P.O. Box \\ 297, 1000 Skopje, Republic of North Macedonia. \\ ${ }^{2}$ Goce Delchev University, Faculty of Agriculture, Krste Misirkov 10-A, P.O. BOX 201, 2000 Stip, Republic of North \\ Macedonia. \\ *Corresponding author: miskoska@yahoo.com
}

Received 17 January 2020; Accepted 26 February 2020

\begin{abstract}
A B S T R A C T
Different types of fertilizers, such as chemical fertilizers, organic fertilizers and natural fertilizers are available on the market. The type of fertilizer has a large impact on plant production quality. The aim of this study, which was conducted under field conditions in the village of Jurumleri near Skopje, North Macedonia, was to investigate the influence of the application of two different types of fertilizers on leaf area and stomatal density in potato. The influence of the microbiological fertilizer Slavol and the organic fertilizer Biohumus was investigated. Also, a control plot without any fertilizer was used. A statistical tool (ANOVA test) was used for data analyses. The results showed that a statistically highly significant difference in average leaf area was found between plants treated with Slavol and plants treated with Biohumus $(\mathrm{p}<0.001)$. Also, a statistically highly significant difference was detected in stomatal density between plants treated with Slavol and control plants $(\mathrm{p}<0.001)$. A very significant difference was noticed between plants treated with Slavol and plants treated with Biohumus $(\mathrm{p}<0.01)$. The microbiological fertilizer Slavol showed better results than Biohumus in our research.

Keywords: potato, leaf, stomatal density, fertilizer.

\section{И 3 В О Д}

Различити типови ђубрива, као што су минерална, органска и природна ђубрива су доступна на тржишту. Тип ђубрива има велики утицај на квалитет биљне производње. Циљ овог истраживања је био, да у пољским условима у селу Јурумлери у околини Скопља, испита утицај примене два различита типа ђубрива на површину листа и густину стоминих отвора код кромпира. Испитвивани су микробиолошко ђубриво Славол и органско ђубриво Биохумус. Контролна парцела није ђубрена. За статистичку анализу је коришћен ANOVA тест. Резултати су показали статистички веома значајну разлику у просечној површини листа између биљака третираних славолом и Биохумусом (р<0.001). Такође, статистички веома значајна разлика је утврђена на густини стоминих отвора између биљака третираних Славолом и биљака на контролној парцели. Веома значајне разлике су утврђене између биљака које су третиране Славолом и биљака које су третиране Биохумусом (p<0.01). Микробиолошко ђубриво Славол је показало боље резултате од Биохумуса.
\end{abstract}

Кључне речи: кромпир, лист, гистина стоминих отвора, ђубриво.

\section{Introduction}

Potato (Solanum tuberosum L.) belongs to the Solanaceae family and it is a globally important crop plant producing high yields of nutritionally valuable food in the form of tubers. Potato tubers are quite rich in carbohydrates and leaves are rich in protein. Therefore, different plant parts can reliably be used as livestock feed (Yildirim et al., 2005).

Several literature reviews have indicated that potatoes produced following organic practices are healthier than potatoes produced using conventional methods. Organic potatoes contain less nitrate (Erhart et al., 2005; Lairon, 2009) compared with conventionally grown potatoes. Likewise, increases in dry matter (Rembialkowska, 1999; Moschella et al., 2005), vitamin C (Hajšlová et al., 2005), phenolic compounds (Hamouz et al., 2005), total amino acids (Maggio et al., 2008), total proteins (Camin et al., 2007; Maggio et al., 2008), total sugars, and mineral elements (Wszelaki et al., 2005; Hajšlová et al., 2005; Rembialkowska, 2007) were noted in organic potatoes compared with conventional potatoes. In other reports, significant differences were not detected between organic and conventional potato tubers regarding starch (Makaraviciute, 2003; Maggio et al., 2008), essential amino acids, reducing sugars and dry matter (Maggio et al., 2008), phenolic compounds (Woese et al., 1997) or ascorbic acid and dry matter (Camin et al., 2007). The main challenge facing organic production is management of nutrients, diseases and insects (Finckh et al., 2006). Potato quality depends on storage management treatments and fertility 
management during production (Gottschalk and Ezhekiel, 2006).

Bio-fertilizers are alternative fertilizers used in organic farming to enhance plant growth and yield. They play a multifunctional role not only in soil improvement by microorganisms, but also as nutrients, stabilizers, hormones and isolates (Mohapatra et al., 2013). The natural microbiological fertilizer Slavol combines nitrogen fixing and phosphorus mineralizing bacteria (Azotobacter chroococcum, A. vinelandi, Derxia sp., Bacillius megaterium, B. lichenformis and B. subtilis). Slavol is known for its positive effects on plant production (Đorđević et al., 2005; Jelačić et al., 2007; Masimović et al., 2102; Miskoska-Milevska et al., 2012; Najdenovska et al., 2012a, 2012b, 2013; Miskoska-Milevska et al., 2018).

The organic fertilizer Biohumus is used to increase soil fertility and yield of agricultural crops. Biohumus is the result of bio processing of livestock and poultry farming waste by the red Californian worm. In previous research, positive effects of Biohumus on plant production were confirmed (Madiyeva et al., 2018; Sonko et al., 2018; Aćimović et al., 2015). Research on bio-fertilizers is necessary for the understanding of their impact on human health, flora, fauna and soil.

Leaf area estimate is an important parameter in understanding photosynthesis, light interception, water and nutrient use, crop growth and yield potential (Smart, 1974; Williams, 1987). A nondestructive estimate of leaf area is imperative in many ecophysiological and agronomic studies. Plant stomata, the vital gate between the plant and atmosphere, may play a central role in plant/vegetation responses to environmental conditions, and they have been investigated from molecular and whole plant perspectives, as well as at ecosystem and global levels (Nilson and Assman, 2007). Many factors such as $\mathrm{CO}_{2}$ concentration, heat stress, salt stress, drought, precipitation change and plant density have effects on stomatal density (Xu and Zhou, 2008).

The aim of this research was to compare the effects of two different fertilizers (Slavol and Biohumus) on potato leaf area and stomatal density.

\section{Material and Methods}

The experimental plot was set up on an alluvial soil, in the village of Jurumleri near Skopje, Macedonia, during the cultivation seasons in 2019. Potato (Solanum tuberosum var. Safari) was used as research material. Safari is a medium-early variety, with a yellow skin color, a high yield potential, and a round-oval shape. The potato was cultivated from tubers and planted in the open field. During the growing season, the plants were treated with the organic fertilizer Biohumus (a liquid fertilizer made of Californian red worms) and the biofertilizer Slavol (which contains nitrogen fixing and phosphorus mineralizing bacteria). The fertilizers were foliarly applied at a concentration of $1 \%$ solution.

The treatments were set in three replications in the following order:

1. $\varnothing$ control - no use of organic fertilizer,

2. T-1 - foliar treatment with Biohumus,

3. T-2 - foliar treatment with Slavol.

Each treatment was applied every 10 days. The treatments started when the plants were $30 \%$ flowering (May 28, 2019 ), the second application of fertilizers was on June 6, 2019 and the third on June 16, 2019.

One month after the last application of fertilizers, leaf length and leaf width were determined by using 30 randomly selected leaf samples. Leaf samples from control plants were used for comparison. Potato leaf area was determined using the model of nondestructive estimation of potato leaf area by Mompie et al. (2014). Also, stomatal density (number per $1 \mathrm{~mm}^{2}$ of leaf area) on both the lower and upper leaf surface was assessed by preparation and microscope examination on nail polish replicas (Brewer, 1992). Average stomatal density was determined, based on 10 leaves per treatment using counts from three areas per leaf.

For data analyses, ANOVA (analysis of variance) test was used. The least significant differences were computed by the LSD test at the level of $p<0.05$, $p<0.01$ and $\mathrm{p}<0.001$

\section{Results and discussion}

Fertilizers are compounds given to plants to promote growth. They can be applied via the soil, for uptake by plant roots or by foliar spraying, for uptake through leaves. One of the methods for enhancing soil fertility and environmental protection in today's market conditions is the efficient use of agro-industrial wastes (manure, poultry litter, waste from meatpacking plants, sugar factories, canneries, sludge treatment plants, residues of crop production, vegetable growing, horticulture, etc.) (Chatellard, 2017).

The environmentally friendly fertilizer Biohumus has a large number of macro and microelements, as well as growth substances, vitamins, antibiotics, amino acids and useful microflora. On the other hand, the application of microbiological fertilizers in plant production can reduce the use of mineral fertilizers, which has an economic benefit, and ensures safe production. In that sense, Slavol as a microbiological fertilizer has shown a generally positive effect in plant production (Đorđević et al., 2005; Jelačić et al., 2007; Masimović et al., 2012; Miskoska-Milevska et al., 2012; Najdenovska et al., 2012a, 2012b, 2013; MiskoskaMilevska et al., 2018).

Leaf area measurements are required by plant physiologists to study primary production, by plant pathologists to be used as a measure of disease severity, and by ecologists who use leaf area relations in describing competition among different plant species (Korva and Forbes, 1995). Sometimes, it is necessary to determine leaf area without destroying the plants. Several non-destructive methods exist for leaf area determination. In this study, potato leaf area was estimated by the nondestructive model of Mompie et al. (2014). 


\section{Table 1}

Average potato leaf area $\left(\mathrm{cm}^{2}\right)$ after treatment with different fertilizers

\begin{tabular}{|l|c|c|c|}
\hline & $\begin{array}{c}\text { Control } \\
\text { plants }\end{array}$ & $\begin{array}{c}\text { Plants } \\
\text { treated } \\
\text { with } \\
\text { Biohumus }\end{array}$ & $\begin{array}{c}\text { Plants } \\
\text { treated } \\
\text { with } \\
\text { Slavol }\end{array}$ \\
\hline $\begin{array}{l}\text { Average leaf } \\
\text { area }\left(\mathrm{cm}^{2}\right)\end{array}$ & 144.22 & 115.46 & 163.28 \\
\hline Minimum & 44.52 & 72.72 & 90.69 \\
\hline Maximum & 276.02 & 182.80 & 273.87 \\
\hline
\end{tabular}

The average leaf area in plants treated with Slavol was the largest. Also, the average leaf area in plants treated with Biohumus was the smallest compared with control plants and plants treated with Slavol (Table 1).

Table 2

Analysis of variance for Table 1.

ANOVA

\begin{tabular}{lcccccc}
\hline $\begin{array}{l}\text { Source of } \\
\text { Variation }\end{array}$ & SS & $d f$ & $M S$ & $F$ & P-value F crit \\
\hline Rows & 64880,92 & 29 & 2237,273 & 0,814 & 0,722 & 1,662 \\
Columns & 34769,6 & 2 & 17384,8 & 6,332 & 0,003 & 3,155 \\
Error & 159229,3 & 58 & 2745,333 & & &
\end{tabular}

Total $\quad 258879,8 \quad 89$

LSD $_{0.05} 27.1758$

$\mathrm{LSD}_{0.01} \quad 36.2304$

$\mathrm{LSD}_{0.001} \quad 47.3002$

According to the LSD-test, the difference in average leaf area between plants treated with Slavol and plants treated with Biohumus was statistically highly significant $(\mathrm{p}<0.001)$. No statistically significant difference in average leaf area was found between plants treated with Biohumus and control plants. The difference in average leaf area between plants treated with Slavol and control plants was not statically significant (Table 2). In contrast, the difference in average leaf area between strawberry plants treated with the microbiological fertilizer Slavol and control strawberry plants was statistically significant (Miskoska-Milevska et al. 2012). Also, Najdenovska et al. (2013) detected statistically significant difference $(p<0.01)$ in average leaf area between treated broccoli plants and control broccoli plants. As reported by Miskoska-Milevska et al. (2018), statistically highly significant difference $(\mathrm{p}<0.001)$ was found in average length of cauliflower plants between plants foliarly treated with Slavol and control cauliflower plants.

Potato has amphistomatous leaves i.e. stomata are on the upper and lower epidermis. As expected, stomatal density on the lower epidermis was higher than on the upper epidermis. Stomatal densities on the upper and lower epidermis in potato plants treated with Slavol and Biohumus versus control plants are presented in Table 3. The average stomatal density on the lower epidermis, as well as total stomatal density were the highest in plants treated with Slavol, followed by plants treated with Biohumus (Table 3 ).
Table 3

Average stomatal density (stomata/ $\mathrm{mm}^{2}$ ) of potato leaves in plants treated with Biohumus and plants treated with Slavol

\begin{tabular}{|c|c|c|c|}
\hline & $\begin{array}{c}\text { Control } \\
\text { plants }\end{array}$ & $\begin{array}{c}\text { Plants } \\
\text { treated } \\
\text { with } \\
\text { Biohumus }\end{array}$ & $\begin{array}{c}\text { Plants } \\
\text { treated } \\
\text { with } \\
\text { Slavol }\end{array}$ \\
\hline $\begin{array}{c}\text { Average } \\
\text { stomatal density } \\
\text { on upper } \\
\text { epidermis } \\
\text { (stomata/mm }{ }^{2} \text { ) }\end{array}$ & 44 & 36 & 46 \\
\hline $\begin{array}{c}\text { Average } \\
\text { stomatal density } \\
\text { on lower } \\
\text { epidermis } \\
\text { (stomata/mm }{ }^{2} \text { ) }\end{array}$ & 128 & 157 & 190 \\
\hline $\begin{array}{c}\text { total stomatal } \\
\text { density } \\
\text { (stomata/mm }{ }^{2} \text { ) }\end{array}$ & 172 & 193 & 236 \\
\hline
\end{tabular}

Statistical analyses found no significant difference between plants treated with Biohumus and control plants, nor between plants treated with Slavol and control plants, regarding the average stomatal density on the upper epidermis. A statistically significant difference was detected only between plants treated with Biohumus and plants treated with Slavol $(\mathrm{p}<0.05)$.

LSD-test showed a statistically significant difference in average stomatal density on the lower epidermis between plants treated with Slavol and control plants $(p<0.05)$. A statistically highly significant difference in average stomatal density on the lower epidermis was found between plants treated with Slavol and control plants $(\mathrm{p}<0.001)$. Also, a statistically very significant difference in average stomatal density on the lower epidermis was detected between plants treated with Slavol and plants treated with Biohumus $(\mathrm{p}<0.01)$ (Table 4).

\section{Table 4}

Analysis of variance for Table 3 (stomatal density on lower epidermis).

\begin{tabular}{|c|c|c|c|c|c|c|}
\hline $\begin{array}{l}\text { Source of } \\
\text { Variation }\end{array}$ & SS & $d f$ & $M S$ & $F$ & $P$-value & F crit \\
\hline Rows & 69866,649 & 29 & 2409,195 & 1,153 & 0,315 & 1,662 \\
\hline \multirow[t]{2}{*}{ Columns } & 56982,786 & 2 & 28491,39 & 13,642 & $<0,001$ & 3,155 \\
\hline & 121126,674 & 58 & 2088,391 & & & \\
\hline Total & 247976,109 & 89 & & & & \\
\hline $\operatorname{LSD}_{0.05}$ & 23.6998 & & & & & \\
\hline LSD $_{0.01}$ & 31.5963 & & & & & \\
\hline $\operatorname{LSD}_{0.001}$ & 41.2501 & & & & & \\
\hline
\end{tabular}

Statistical analyses of data indicated a statistically highly significant difference between plants treated with Slavol and control plants regarding total stomatal density $(\mathrm{p}<0.001)$. A statistically very significant difference was found in total stomatal density between 
plants treated with Slavol and plants treated with Biohumus $(p<0.01)$. No significant difference in total stomatal density was detected between plants treated with Biohumus and control plants (Table 5).

Table 5

Analysis of variance for Table 3 (total stomatal density).

ANOVA

\begin{tabular}{|c|c|c|c|c|c|}
\hline $\begin{array}{l}\text { Source of } \\
\text { Variation }\end{array}$ & SS & $d f$ & $M S$ & $F$ & $P$-value F crit \\
\hline Rows & 70597,2862 & 29 & 2434,389 & 0,941 & $0,5601,662$ \\
\hline Columns & 62975,3182 & & 31487,66 & 12,172 & $<0,0013,155$ \\
\hline Error & 150027,628 & 58 & 2586,683 & & \\
\hline
\end{tabular}

Total $\quad 283600,232 \quad 89$

LSD $_{0.05} \quad 26.3761$

$\mathrm{LSD}_{0.01} \quad 35.3071$

LSD $_{0.001} \quad 46.0947$

The results of t-test indicated a statistically significant difference in total stomatal number between strawberry plants treated with Slavol and control strawberry plants (Miskoska-Milevska, 2012). Miskoska-Milevska (2018) found a statistically highly significant difference in total stomatal density between cauliflower plants treated with Slavol and control plants $(\mathrm{p}<0.001)$.

\section{Conclusions}

A statistically highly significant difference in average leaf area was found between plants treated with Slavol and plants treated with Biohumus $(p<0.001)$. No significant difference was found in average leaf area between plants treated with Biohumus and control plants. The difference in average leaf area between plants treated with Slavol and control plants was not statically significant.

For stomatal density, a statistically very significant difference was found between plants treated with Slavol and plants treated with Biohumus $(\mathrm{p}<0.01)$. There was a statistically highly significant difference between plants treated with Slavol and control plants regarding total stomatal density $(\mathrm{p}<0.001)$. No significant difference was found in total stomatal density between plants treated with Biohumus and control plants. The microbiological fertilizer Slavol showed better results than Biohumus in our research.

\section{References}

Aćimović, M.G., Dolijanović, Ž.K., Oljača S.I., Kovačević, D.Đ., Oljača M.V. (2015). Effect of Organic and Mineral Fertilizers on Essential oil Content in Caraway, Anise and Coriander Fruits. Acta Scientarium Polonorum Hortorum Cultus, 14(1), 95-103.

Brewer, C.A. (1992). Response by Stomata on Leaves to Micro Environmental Conditions. In. Goldman, C.A. (ed.), Tested Studies for Laboratory Teaching. Proceeding of the $13^{\text {th }}$ Workshop/ Conference of the Association for Biology Laboratory Education (ABLE), 13, 67-77.

Camin, F., Moshella, A., Miselli, F., Parisi, B., Versini, G., Ranalli, P., Bagnaresi, P. (2007). Evaluation of the markers for the traceability of potato tuber grown in an organic and versus conventional regime. Journal of the Science of Food and Agricuture, 87, 1330-1336.

Chatellard, L. (2017). Trends and Challenges in Biohydrogen Production from Agricultural Waste. Biohydrogen Production: Sustainability of Current Technology and Future Perspective.

Đorđević, S., Đurić, N., Trkulja, V., Najdenovska, O., Gavrilović, M. (2005). The influence of seed bacterial inoculation on productivity of various wheat varieties. Zbornik naučnih radova $V, 11(1-2), 41-48$

Erhart, E., Harlt, W., Putz, B. (2005). Biowaste compost affects yield, nitrogen supply during the vegetation period and crop quality of agricultural crops. European Journal of Agronomy, 23, 305-314.

Finckh, M.R., Schulte-Geldermann, E., Bruns, C. (2006). Challenges to organic potato farming: disease and nutrient management. Potato Research, 49, 27-42.

Gottschalk, K., Ezhekiel, R. (2006). Storage. In: Handbook of potato production, improvement, and postharvest management. Food Products Press, New York London, 489-522.

Hajšlová, J., Schulzová, V., Slanina, P., Jannè, K., Hellenäs, K.E., Andersson, C. (2005). Quality of organically and conventionally grown potatoes: four-year study of micronutrients, metals, secondary metabolites, enzymatic browning and organoleptic properties. Food Additives and Contamitants, 22, 514-534.

Hamouz, K., Lachman, J., Dvořák, P., Pivec, V. (2005). The effect of ecological growing on the potatoes yield and quality. Plant, Soil and Environment, 51, 397-402.

Jelačić, S., Betadović, D., Akić, N., Vujošević, A. (2007). The effect of natural biostimulators and slowdisintegrating fertilizer on the quality of rosemary seedlings (Rosmarinus officinalis L.). Journal of Agricultural Sciences, 52(2), 85-94.

Korva, J.T., Forbes, G.A. (1995). A Simple Non-destructive Technique for Healthy and Diseased Leaf Area Assessment of Potato Plants. Potato Research, 38, 31-37.

Larion, D. (2009). Nutritional quality and safety of organic food a review. Agronomy for Sustainable Development, 30 (1), 33-41.

Madiyeva A., Galaktionova V., Kupčinskieè E. (2018) . Efficiency of application of fertilizers Biohumus and Gumint at cultivation of Sudan grass (Sorghum sudanense L.) on seeds in the conditions of Northern Kazakhstan. Žmogaus ir gamtos sauga, 109-112.

Maggio, A., Carillo, P., Bulmetti, G.S., Fuggi, A., Barbieri, G., Dr Pascale, S. (2008), Potato yield and metabolic profiling under conventional and organic farming. European Journal of Agronomy, 28, 343-350.

Makaraviciute, A. (2003). Effect of organic and mineral fertilizers on the yield and quality of different potato varieties. Agronomy Research, 1, 197-209.

Masimović, M., Vukojević, D., Zavišić, N., Simić, J., Vidić, M. (2012). Utecaj mikrobiološkog gnojiva Slavol na sprečavanje opadanja plodova jabuke pred berbu. Proceedings. 47th Croatian and 7th International Symposium on Agriculture. Opatija. Croatia, 807-811.

Miskoska-Milevska, E., Najdenovska, O., Selamovska A., Popovski, Z., Đorđević, S. (2012). The Effect of Microbiological Fertilizer - Slavol on Strawberry Leaf Area and Stomatal Number. Soil and Plant, 61(3), 147158.

Miskoska-Milevska, E., Najdenovska, O., Popovski, Z.T., Dimovska, D. (2018). The influence of the microbiological fertilizer - Slavol on cauliflower growth. Romanian Biotechnological Letters, 23(2), 13511-13516.

Mohapatra, S.K., Munsi, P.S., Mahapatra, P.N. (2013). Effect of integrated nutrient management on growth, yield and economics of broccoli (Brassica oleracea L. var. italic Plenck.). Vegetable Science, 40(1), 69-72.

Mompie, E.J., Martìn, R.M., Hernández, Y.D. (2014). Estimate of the Leave Area in Two Potato Varieties (Solanum tuberosum L.) for Non Destructive Methods. Cultivos Tropicales, 35(1), 57-61. 
Moschella, A., Camin, F., Miselli F., Parisi, B., Versini, G., Ranalli, P. (2005). Markers of characterization of agricultural regime and geographical origin in potato. Agroindustria, 4(3): 325-332.

Najdenovska, O., Đorđević, S., Miskoska-Milevska, E., Dimovska, D., Popovski, Z. (2013). Determination of Broccoli Leaf area and Stomatal number using Different Application Methods of Microbiological Fertilizer-Slavol. Soil and Plant, 62(1), 1-13.

Najdenovska, O., Selamovska, A., Đorđević, S., MiskoskaMilevska, E., Stojanova, M., Iljovski, I., Arsov, Z. (2012a). The Influence of Microbiological Fertilizer on the Generative Potential and Yield of Strawberry. Soil and Plant, 61(3), 138-145.

Najdenovska, O., Stojanova, M., Miskoska-Milevska, E. Dimovska, D., Đurić , S., Čolo, J. (2012b). Influence of Microbiological fertilizer in Lettuce and Swiss Chard production. 16thInternational Eco-Conference. Ecological movement of Novi Sad, 201-207.

Nilson, S.E., Assmann, S.M. (2007). The control of transpiration. Insights from Arabidopsis, Plant Physiology, 143, 19-27.

Rembialkowska, E. (1999). Comparison of the contents of nitrates, nitrites, lead, cadmium and vitamin $\mathrm{C}$ in potatoes from conventional and ecological farms. Polish Journal of Food and Nutrition Science, 8(49): 17-26.

Rembialkowska, E. (2007). Quality of plant products from organic agriculture. Journal of the Science of Food and Agricultre, 87, 2757-2762.
Smart, R.E. (1974). Photosynthesis by grapevine canopies. Journal of Applied Ecology, 11(3), 997-1006.

Sonko, S.P., Vasilenko, O.V., Sukhanova, I.P., Shchetyna, M.A., Hurskiy, I.M. (2018). Vermiculture as in important component of ecologically tolerant agricultural ecosistems. Ukrain Journal of Ecology, 8(4), 236-242.

Williams, L.E. (1987). Growth of "Thomson Seedless" grapevines: I. Leaf area development and dry weight distribution. Journal of American Society and Horticultural Science, 112(2), 325-330.

Woese, K., Lange, D., Boess, C., Bogl, K.W. (1997). A comparison of organically and conventionally grown foods result of a review of the relevant literature. Journal of the Science of Food and Agricultre, 74, 281-293.

Wszelaki, A.L., Delwiche, J.W., Walker, S.D., Liggett, R.E., Joseph, C., Scheerens, J.C., Kleinhenz, M.D. (2005). Sensory quality and mineral and glycoalkaloid concentrations in organically and conventionally grown redskin potatoes (Solanum tuberosum L.). Journal of the Science of Food and Agricultre, 85, 720-726.

Xu, Z., Zhou, G. (2008). Responses of leaf stomatal density to water status and its relationship with photosynthesis in a grass. Journal of Experimental Botany, 59(12), 33173325.

Yildirim, B., Tuncturk, M., Cieftci, C. (2005). Effects of Various Planting Times on the Yield and Yield Traits of Different Potato Cultivars (Solanum tuberosum L.). Yuzuncu Yil Univ. Journal of Agricultral Science, 15(1), 1-9. 